\title{
Incorporating a Systemic and Foresight Approach into Smart City Initiatives: The Case of Spanish Cities
}

José-Miguel Fernández-Güell, Marta Collado-Lara, Silvia Guzmán-Araña and Victoria Fernández-Añez

ABSTRACT At the dawn of the twenty-first century, cities face serious societal, economic, environmental, and governance challenges. Under the term "Smart City," numerous technology-based initiatives are emerging to help cities face contemporary challenges while the concept itself is evolving towards a more holistic approach. Nevertheless, the capability of smart initiatives to provide an integrated vision of our cities is still very limited. Eventually, many of these initiatives do not fulfill satisfactorily their initial objectives because they fail to understand the complexity, diversity, and uncertainty that characterize contemporary cities. The purpose of this paper is twofold: to display an urban functional system, capable of interpreting the city in a more holistic way, and to incorporate foresight tools so as to formulate Smart City visions in a more participatory way with the involvement of local stakeholders.

KEYWORDS smart city; urban complexity; systemic approach; foresight tools; urban visions

\section{Introduction}

At the beginning of the twenty-first century cities are posing serious challenges because their number and size are growing at unprecedented rates. According to UN projections, by 2050 around 66 percent of the world population will live in urbanized areas and by 2030 there will be more than 650 cities with over one million inhabitants (UN-DESA, 2014). This urbanization spree is making most municipal governments conscious about environmental issues such as improving energy efficiency, diminishing emissions, and preserving biodiversity. Likewise, urban leaders are very much concerned with increasing economic competitiveness and strengthening social cohesion, goals which are sometimes at odds with environmental priorities.

Faced with growing challenges, municipal leaders and local stakeholders are increasingly turning their attention toward the so-called Smart City (SC) initiatives that make extensive use of technology to solve urban problems. Despite the relative youth of most SC initiatives, it is already possible to discern on

Correspondence Address: José-Miguel Fernández-Güell, Deputy Director of Research at the School of Architecture, Universidad Politécnica de Madrid; Professor of the Urban and Regional Planning Department at the Universidad Politécnica de Madrid, Spain. E-mail: josemiguel.fernandez@upm.es 
this topic two sides with strong opinions: on the one side, there are those who advocate for incorporating smart technologies in the urban fabric; and on the other side, there is a growing group of critical voices worried about the excessive role given to technology when managing a city. In the midst of this debate, most urban planners seem either perplexed or even resentful about the growing lead that Smart City initiatives are taking within their professional realm.

Besides the growing debate that SC initiatives are stirring up, the seemingly unapproachable complexity and intricate diversity of contemporary cities are hindering, for the time being, conceptual and technical progress in this kind of initiative. Most professional and academic contributions in recent times recognize the need for developing more integrated and holistic approaches to SCs (Chourabi et al., 2012; Perboli et al., 2014; Gil-García et al., 2015). In fact, the SC concept is evolving from the simple inclusion of technology in the city to the development of solutions to urban challenges in an interconnected and synergic manner; however, little real progress can be observed in this direction (Lombardi et al., 2012; Mattoni et al., 2015).

Therefore, this paper proposes a novel approach that displays the systemic functioning and foreseeable evolution of contemporary cities so that SC initiatives can be better assessed not only by technologists and urban planners, but also by a wide range of local stakeholders with no profound expertise in either technology or urban planning. This new approach was applied to a foresight exercise undertaken to envision the desired future of Spanish cities in the 2030 horizon. In brief, this paper pursues two major objectives: (1) to understand the city as a functional system in which SC initiatives are considered from a holistic view; (2) to incorporate foresight tools to assess how SC initiatives may help to achieve the desired future model of a city. In our view, the combination of functional systems with foresight tools provides useful insights about how contemporary cities operate and evolve, and it facilitates the involvement of local stakeholders in the planning of SCs.

Apart from the introduction, this paper is structured in six sections. In the first one, a brief description is given of the nature and challenges of contemporary cities. The second section discusses the pros and cons of Smart Cities. The third section presents the methodological framework followed in the study, paying special attention to the participatory process. The fourth section implements the proposed model framework to envision the future development of Spanish cities. The final sections discuss research results and offer some conclusions about the systemic approach and the application of foresight tools.

\section{Understanding the Nature and Challenges of Contemporary Cities}

Complexity, diversity, and uncertainty are the three key attributes that characterize contemporary cities (Camagni, 2003; Fernández Güell, 2006). A close look at those three characteristics may provide a clearer understanding of cities' nature to professionals not directly involved in city sciences.

The first common feature of all large and medium size cities is the high level of complexity of operational processes that take place within the city limits and in its hinterland. Indeed, it is widely accepted that cities are one of the greatest examples of complex systems (Allen, 1997; Meyers, 2009; Portugali et al., 2012). As a general rule, complex cities experience unpredictable non-linear dynamics, and they are capable of self-transformation in changing contexts. Therefore, 
urban problems are multidimensional since they surge in an intricate and dynamic network of relationships among societal, economic, environmental, and political issues. That is why complexity has been a recurrent handicap for urban planners because it makes urban analysis and policymaking difficult.

The second feature inherent to any big and medium size city is diversity. This important, but elusive feature has been analyzed by well-known authors from different perspectives (Jacobs, 1961; Alexander, 1965; Innes and Booher, 1999). Basically, urban diversity is generated by the disparity and heterogeneity of local agents who intervene in the socioeconomic activities of a city. In other words, highly sophisticated and diversified city functions are matched by a wide variety of local and supra local agents with differing and sometimes opposing interests. Under those conditions, in a democratic urban community, political decisions emerge from the input of diverse interest groups with different levels of power. In brief, diversity is an important asset of cities as far as the different interests of urban stakeholders are harmonized in benefit of the whole community.

The third attribute of the urban realm is uncertainty. All kinds of changes constantly affect cities, generating growth, stagnation, or decline. Obviously, changes introduce a high dose of uncertainty in planners' forecasts (Abott, 2005; Klosterman, 2013). Anyone who is responsible for foreseeing the evolution of a city in the long term suffers the limitations of present forecasting tools. Most of the difficulties encountered by forecasters are due to the highly complex and dynamic nature of contemporary cities, which impedes foreseeing events in a precise and reliable way. This situation is aggravated when the city operates within a turbulent and changing context. Faced with these difficulties, many planners just give up long-range planning and focus on contingency planning.

Those three urban attributes are further complicated by a number of significant changes that most contemporary cities face in higher or lesser degree according to their development level. A brief summary of major urban change factors is shown in Figure 1, based on recent foresight reports and articles (Boden et al., 2010; Misuraca \& Lusoli, 2010; EC, 2011; PwC, 2011; UN-Habitat, 2011; Batty et al., 2012; OECD, 2012; OECD, 2015; UN-DESA, 2015).

Though limited, these trends provide a plausible sample of the numerous and complex challenges that most cities in the world will face in the next 10 to 20 years. Some of those changes are already taking place and some others will happen in the near future. No doubt the increasing levels of complexity, diversity, and uncertainty will entice planners and local stakeholders to develop new ways for planning cities in the twenty-first century.

\section{Are Smart Cities the Solution?}

Confronted with these challenges, many cities have found in smart initiatives a strategic option to pull out from present and future problems by heavily investing in technology-oriented solutions. As a matter of fact, nowadays the Smart Cities (SCs) concept has gained wide popularity among the media, social networks, and the political realm as numerous worldwide seminars and conferences devoted to SCs demonstrate. Not only big corporations are creating big expectations around SCs because of business interests (Paroutis et al., 2014; Söderström et al., 2014), also intergovernmental organizations such as the European 


\section{Economic Change Factors}

- Continued globalization

- Consolidation of emergent economies

- Specialization of cities through value chain production

- Company location according to intangible factors

- Dominance of the knowledge-based economy

Transformation of distribution channels by ICTs

Technological Change Factors

- Large investments in developing new energy sources

- Development of new technologies for reducing $\mathrm{CO}_{2}$ emissions

- Continuous investments in ICT infrastructures to support SC projects

- Innovations in big data, open data, and cloud computing

- Substantial progress in nanotechnology and advanced materials

- Continuous innovations in the car industry

\section{Governance Change Factors}

- More participatory democracy

- Increasing political \& administrative decentralization

- More effective coordination among public bodies

- More public-private cooperation

- More integrated sectoral policies

- Innovative management systems at the local level

\section{Societal Change Factors}

- Increasing population living in urban areas

- Diminishing fertility rates

- Massive incorporation of women into the labor force

- Appearance of new forms of social exclusion

- Emergence of new urban life styles

- Increasing migration flows escaping from poverty

Figure 1: Urban change factors. Source: Authors' elaboration

Commission are strongly betting on SC initiatives as a key strategy to promote widespread innovation (EC, 2012, 2013).

Despite its current popularity, there is widespread confusion about what the term Smart Cities really means. Borrowing from different sources (Caragliu et al., 2011; Chourabi et al., 2012; Angelidou, 2014), we conceive Smart Cities as those innovative urban systems that strategically invest in new technologies and human capital, seeking to improve services effectiveness, quality of life, economic competitiveness, environmental sustainability, and participatory governance. Additionally, we state that SC initiatives should address the complexity, diversity, and uncertainty inherent in urban systems under a holistic and integrated approach.

Since its inception in the 1990s, the SC concept has been strongly marked by technology as the key driver to face the major challenges of contemporary cities. At its initial stages, SCs mostly focused on increasing the efficiency and sustainability of public services so as to improve citizens' quality of life. Therefore, tech initiatives were geared to improve energy efficiency, diminish $\mathrm{CO}_{2}$ emissions, strengthen city safety, and alleviate traffic congestion. In general terms, these types of SC initiatives tried to solve sectoral problems by operating in technological silos (Caragliu et al., 2011; Fernández Güell, 2015).

In the last few years, the focus of SCs has significantly been extended to societal, economic, and governance concerns. In fact, it is quite common to find nowadays SC initiatives that pursue more complex objectives such as improving quality of life, increasing economic competitiveness, or providing more transparent participatory processes (Giffinger et al., 2007). These initiatives correspond to a 
much more integrated SC model in which inter-sectoral functionalities are being developed within larger technological platforms. Nevertheless, we are still far away from achieving a truly holistic model for SCs.

Though it is not easy to discern between the costs and benefits of SCs because of their relatively short existence, there is already plenty of literature about their potential pitfalls and windfalls (Angelidou, 2014; Glasmeier and Christopherson, 2015; Kitchin, 2015). According to their advocates, SCs offer an ample set of benefits to solve urban dilemmas (IBM, 2009; Campbell, 2012; Cisco 2013; Siemens, 2015). They argue that SCs improve the efficiency of public services provision because they reinforce management capacities, diminish resources consumption, and reduce public expenditures. SCs provide agile and personalized services to citizens according to their specific needs, improving in turn their quality of life. SCs strengthen city safety by monitoring transport systems, preventing street crime, and responding faster to emergencies. SCs represent a significant support for decision-making because they provide intelligent information in real time from urban systems through a vast network of sensors. SCs stimulate innovation because they generate multiple opportunities for the development of new ideas and business in order to satisfy new urban demands. SCs enable the establishment of advanced governance models. Because they identify citizens' needs, they facilitate the access to transparent information, and they favor citizens' participation in government.

Despite these predicted advantages, SCs also display some potential threats, expressed by numerous critical voices, which should be seriously taken into account (Hollands, 2008; Greenfield, 2013; Townsend, 2013; Söderström et al., 2014; Vanolo, 2014). SCs tend to offer intelligent solutions strictly through technology while there are other spatial, economic, social, and political instruments that can also provide intelligence to the city. Excessive emphasis on getting economic benefits, such as productivity and efficiency, may expose SCs to strong lobby interests from big corporations. Some SC initiatives require large investments with uncertain long-term returns, while proponents seem not interested in assessing its convenience, rationality, and long-term usefulness. The abuse in the use and exploitation of data from citizens may result in stronger social control and the loss of privacy. Above all, most SC initiatives suffer from a lack of understanding of urban complexity because they are operating in technological silos, and so far they have not been capable of developing holistic visions of contemporary cities.

Among advocates and critics of SCs, the voice of urban planners is increasingly heard in the present debate. Though there is not a sound study about the planners' positions on SCs, some scattered references offer a clue to how Smart Cities are perceived with either reluctance or skepticism (Fariña, 2012; Papa et al., 2013; Townsend, 2013; March and Ribera-Fumaz, 2014). First of all, the lack of understanding of the complexities and dynamics of cities by technologists may render useless some investments in SC initiatives. Second, SCs tend to envision the future in a technology-oriented approach, leaving aside the social and political dimensions of urban visions. Third, planners are concerned about granting citizen and stakeholder participation when designing and implementing SC initiatives. Fourth, SC initiatives are said to be our gateway to a better future, but it is hard to find examples of serious foresight exercises in SC initiatives. Finally, a conflictive tension is developing between promoters of SCs and urban planners, mainly due to the lack of common ground from which to discuss their different views about how to approach the challenges of contemporary cities. 
In the specific case of Spain, Smart Cities initiatives are catching the attention of large and small communities. As a matter of fact, Spain is one of the European countries with the most SC initiatives underway, particularly related to smart governance, smart energy, and smart mobility. Some flagship cases, such as Barcelona, Málaga, and Santander, are well known internationally by SC experts. This hype momentum has been fueled by EU research programs (EC, 2013) and state financial support of public-private partnerships (MINETUR, 2015).

Despite their strong commitment, Spanish Smart Cities deserve critical scrutiny and evaluation. According to a recent official assessment (MINETUR, 2015), SC initiatives are very heterogeneous and disconnected from the urban planning strategies followed by the cities, so they tend to be costly because it is difficult to replicate them and obtain economies of scale. Those features represent significant barriers to extending SC initiatives, especially among small and medium-size municipalities.

Without questioning the undisputed role that new technology plays in contemporary societies, we argue the need for not ignoring other critical dimensions of our cities when developing SCs initiatives. A Smart City should consider the human dimension of the city by respecting its complexity and diversity; it should assume its unpredictable behavior by learning to manage uncertainty; it should enhance traditional and well-tested solutions by urban planners; and it should promote an advanced governance model by involving as many stakeholders and citizens as possible. In our opinion, capturing the full potential of SC initiatives will require the joint application of a systemic and foresight approach to enlighten local stakeholders about their opportunities.

In fact, SCs could provide reasonable answers to the three basic challenges of contemporary cities: (1) how to understand and express intelligibly the complexity of cities; (2) how to incorporate the diversity of urban actors in the decisionmaking process; (3) how to assess and manage uncertainty which emanates from continuous change. Related to those questions, other critical issues arise: (a) how to link SC initiatives with the urban planning process; (b) how to incorporate foresight into the design of SCs; (c) how to develop an intelligible model that would allow collaboration among technologists, urban planners, and local stakeholders. If those issues were conveniently addressed, we might be on the path to achieving a holistic and shared vision of a Smart City.

\section{Methodological Framework}

One way to deal with the complexity, diversity, and uncertainty of contemporary cities and at the same time interpret their growing challenges is to conceptualize the city as an evolving, functional ecosystem. Additionally, the systemic approach should be reinforced by foresight tools as part of the planning process, thus helping planners and stakeholders look beyond their short-term problems. Let's explain briefly what complex systems and foresight are.

Based on several contributions made in the field of systems theory (Bertalanffy, 1968; Forrester, 1969; Waldrop, 1992; Kauffman, 1995), a complex system may be defined as a large number of elements that interact among themselves and with the context in which they operate. Complex systems are dynamic since they have the ability to generate new collective behavior through self-organization. Therefore, complex systems are adaptive as they evolve and are not readily 
predictable because they do not necessarily act in a deterministic fashion. In short, complex systems are much more than a sum of their parts.

Regarding foresight, it can be defined as a systematic, participatory, futureintelligence-gathering, and long-term vision-building process aimed at taking present-day decisions and mobilizing joint actions (FOREN, 2001; Abott, 2005). While forecasting relies mainly on quantitative tools to foresee the future, foresight usually employs qualitative tools such as scenarios and visions. Foresight allows us to analyze, assess, and manage uncertainty, which is by itself a valuable exercise for city decision-makers, even if forecasts are not accurate.

Therefore, in order to make SC initiatives more aligned with the pressing needs and challenges of contemporary cities, a methodological framework has been developed which provides a joint systemic and foresight approach to both urban planners and technologists. This model framework consists of five sequential steps (See Figure 2).

Step 1: Conceptualize the city as a functional system. In order to envision its complex and diverse nature, the city is conceptualized as a functional system and displayed by a conceptual map.

Step 2: Check the present validity of the functional system. The proposed functional system is tested in a specific urban case and its legibility is verified by local stakeholders.

Step 3: Incorporate foresight tools to envision the future of cities. To deal with the uncertainty of future events, foresight tools are used to envision the foreseeable evolution of cities.

Step 4: Flesh out the vision's implications on the functional system. Finally, implications are inferred from the future vision into the form and operations of the urban functional system.

Step 5: Involve experts and stakeholders. As a transversal element, stakeholders' involvement along the process not only provides useful insights, but promotes mutual learning between private and public agents, stimulates community participation, and creates ownership of the SC initiatives.

This methodological framework may provide conceptual support to SC initiatives that presently struggle to display a holistic understanding of a city's structure and operations (See Figure 2). The proposed method was developed over a two-year period and it was applied to envision the future development of Spanish cities. Due to the scarcity of research resources and the complexity of the topic, progress was based in a mix of consulting and academic activities. The chronological sequence of the research methodology was roughly as follows. In June 2013, a horizon scanning analysis was undertaken as an internal university project to identify and assess those major change factors that might affect Spanish cities in the next 10-15 years. Scanning the cities' operational context was performed by the so-called STEEP analysis, which stands for Societal, Technological, Economic, Environmental, and Political change factors (UNIDO, 2005). One hundred and ten change factors were identified and assessed according to their level of impact on the urban realm and their certainty of occurrence.

In 2014, a foresight exercise, financed by the company PricewaterhouseCoopers, was undertaken to envision how Spanish cities should desirably evolve in the horizon 2030 taking advantage of advanced "smart initiatives" (Fernández Güell and Collado, 2014). This exercise involved four stages. First, a documented recollection of relevant Smart City projects was made through secondary sources. Second, a systemic conceptual model was developed to understand the city in a 


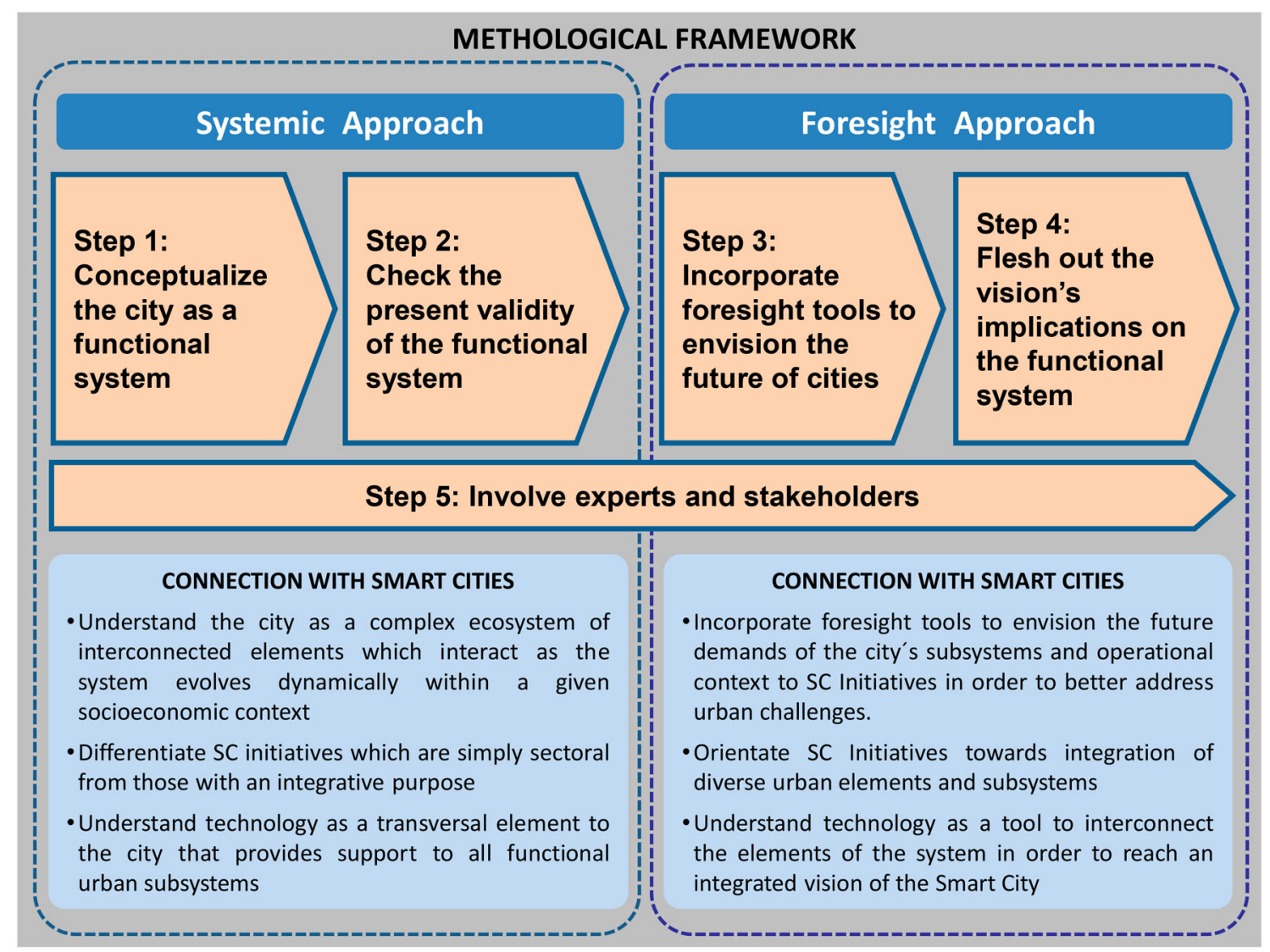

Figure 2: Methodological framework. Source: Authors' elaboration 
holistic way. Third, a foresight exercise was undertaken using three tools: horizon scanning, scenario design, and visioning. Fourth, the resulting future desired vision for Spanish cities and its foreseeable impact in the urban functional system was contrasted and discussed with diverse stakeholders involved in Smart City initiatives around Spain.

This foresight exercise was supported by a strong participatory process. Based on previous empirical analysis of Smart City cases, a list of potential stakeholders based in municipalities, related government agencies, research centers, and technology companies involved in Smart City initiatives was drawn. Twenty-five high-level experts were selected according to their recognized expertise and their ability to envision the future.

Based on semi-structured questionnaires, 13 in-depth interviews of stakeholders were conducted to validate the urban functional system and the future vision for Spanish cities. Interviews required two hours each and were complemented with additional information offered by the interviewees. After the interviews, some subsystems and functional elements were graphically reconfigured and redefined for clarity.

Additional refinements were incorporated into the urban functional system by participating in several professional conferences about Smart Cities. By this time, confidence was gained by the research team about the usefulness of combining a systemic and foresight approach to make SC initiatives more intelligible to wider audiences.

\section{Implementing the Model Framework}

In the following sections, the five methodological steps are implemented to envision the future development of Spanish cities as a desired departure from the previous and arguable urban policies followed prior to the economic recession. This case should be treated as a simple demonstration of the kind of results that can be obtained with the proposed methodological approach.

Though restricted to Spanish cities, the example of implementing the proposed model framework could provide some conceptual clues to those cities that have experienced boom and bust economic episodes, to those cities strongly seduced by SC initiatives mostly limited to sectoral applications, and to those cities willing to reconcile sustainability, competitiveness, and cohesiveness goals under a progressive governance model.

\section{Step 1: Conceptualize the City as a Functional System}

A city may be regarded as a complex ecosystem of connected elements or parts with common purposes, in which human activities, linked by communications, interact as the system evolves dynamically within a given socioeconomic and physical context (Berry, 1964; Churchman, 1968; McLoughlin, 1969). In other words, a city is built from multiple singular initiatives taken through time by a great number of players who are tightly interconnected among themselves. In this ecosystem, any spatial or structural alteration in one of its elements can modify the other parts of the system.

Compared to other functional systems, cities have some distinctive features that should be taken into consideration (Batty, 2005; Fernández Güell, 2006). The change process in the city is not sequential (one thing directly affecting 
another), but rather simultaneous (many things happening at the same time). The city is a functional system with a heavy inertia, so there are limits to a city's ability to accelerate or slow down the pace of change. Cities are immersed in a space configured by infrastructures and natural features, all of which influence its functional dynamics. A city is part of a higher functional system, in which a number of cities are linked together by innumerable economic, social, and spatial relationships (Berry, 1964; Allen, 1997; Camagni, 2003). Finally, such a complex system is constantly reacting to external changes, so cities strive to adapt or dominate them, otherwise they decline.

For the purpose of explaining the complex functioning of a contemporary city, a conceptual model was developed in which the urban ecosystem was synthesized and visualized as a set of different interrelated subsystems (See Figure 3). First of all, the urban demand (composed of citizens, economic agents, societal institutions, and visitors) was placed in the center of the model. All of them pose a number of requirements on resources, services, and infrastructures provided by the urban subsystems so that they can live and work in a city under good conditions. Second, from the supply side, the societal, economic, environmental, and political subsystems of the city strive to interpret and satisfy requirements from the different demand segments. Every subsystem is described by its resource capital, operating agents, services provided, and technology used. Third, those four supply subsystems request specific physical conditions to the spatial subsystem to operate properly. Thus, the spatial subsystem, regulated by urban planning, is responsible for providing basic infrastructures, transport systems, and a wide range of community facilities and housing units. Fourth, all the previous functional subsystems and demand segments are served by a technological subsystem made up of multiple platforms, which ideally should be horizontal in nature, though they just may

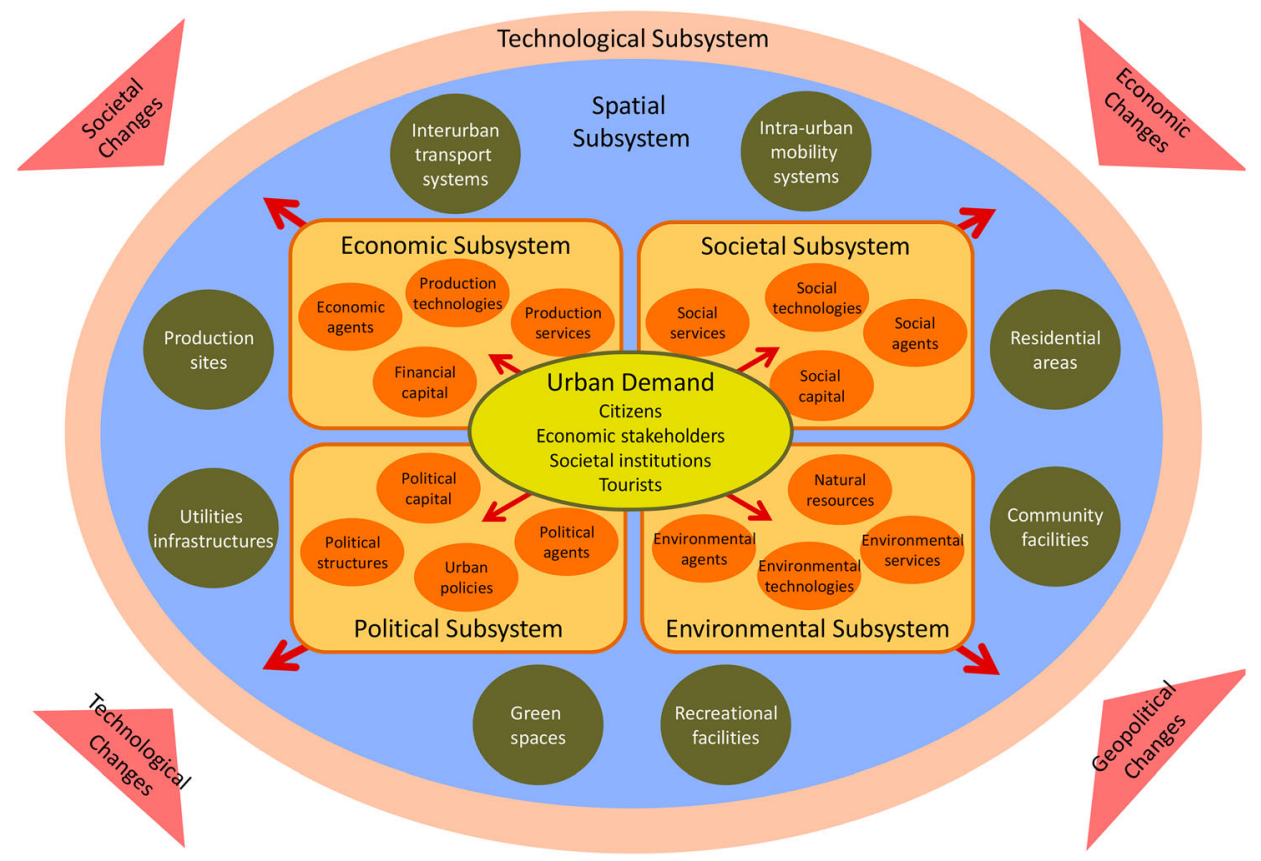

Figure 3: A city's functional system. Source: Authors' elaboration 
operate for a single sector. Finally, the overall urban system is subject to external change factors, such as demographic transformations, economic cycles, technological innovations, or environmental impacts, which affect its functional balance. Indeed, in reality this flow does not happen in such a linear sequence since there are plenty of loops and feedbacks among urban subsystems.

Though it can be perceived as reductionist, this systemic conceptualization of the city has a clear advantage: it displays a simplified, intelligible abstraction of the inherent complexity of our urban reality, which is easily understood by technicians, local stakeholders, and citizens. Moreover, it can schematically express the dynamic evolution that a city may undergo through a given period of time, sequencing past, present, and future, thus providing a useful support for undertaking the foresight exercise. It may also critically analyze the diverse relationships between urban components as well as expose the dominance or dependence positions of both stakeholders and functional subsystems. From our perspective, the systemic approach strives to reach a better understanding of the underpinnings of the urbanization process as well as to establish a common ground for reconciling technologists and urban planners.

\section{Step 2: Check the Present Validity of the Functional System}

The urban functional system shown in the conceptual framework was used to characterize the development model followed by most Spanish cities during the 2000-2008 period, when the country enjoyed a long economic bonanza that nurtured a huge real estate speculative bubble. The successes and excesses made at that time constitute an interesting experience to study before formulating the future model for more sustainable, competitive, and cohesive cities, supported by innovative technologies. The following retrospective analyses are synthesized from secondary sources (Jiménez, 2009; Naredo and Montiel, 2011; Gaja i Díaz, 2015) and contributions made by the experts during the foresight exercise.

According to the proposed functional system, in those years Spanish cities were operating as follows (See Figure 4):

Urban Demand. Its major segments were fragmented and scarcely connected among themselves when dealing with urban issues. Businessmen behaved opportunistically with short-term actions, contemplating the city just as a chess board served by good public infrastructures and facilities in which they could easily make multiple speculative and profitable deals. Regarding citizens, most of them were satisfied with the socioeconomic context, so they were unconcerned with urban issues. Tourists would arrive at city destinations expecting all kind of facilities and services to fulfill their highest aspirations, regardless of the environmental or social effects they might have.

Economic Subsystem. It showed good performance indicators in growth and employment, but it also suffered from structural weaknesses related to low productivity levels and excessive financial leverage. Except in big metropolises, like Madrid and Barcelona, most municipal economic bases were dominated by small and medium enterprises in mature industries which had low technological intensity and were mainly oriented to the national market.

Societal Subsystem. The social fabric of many Spanish cities revealed the tensions generated by the progressive ageing of urban populations, the wave of 


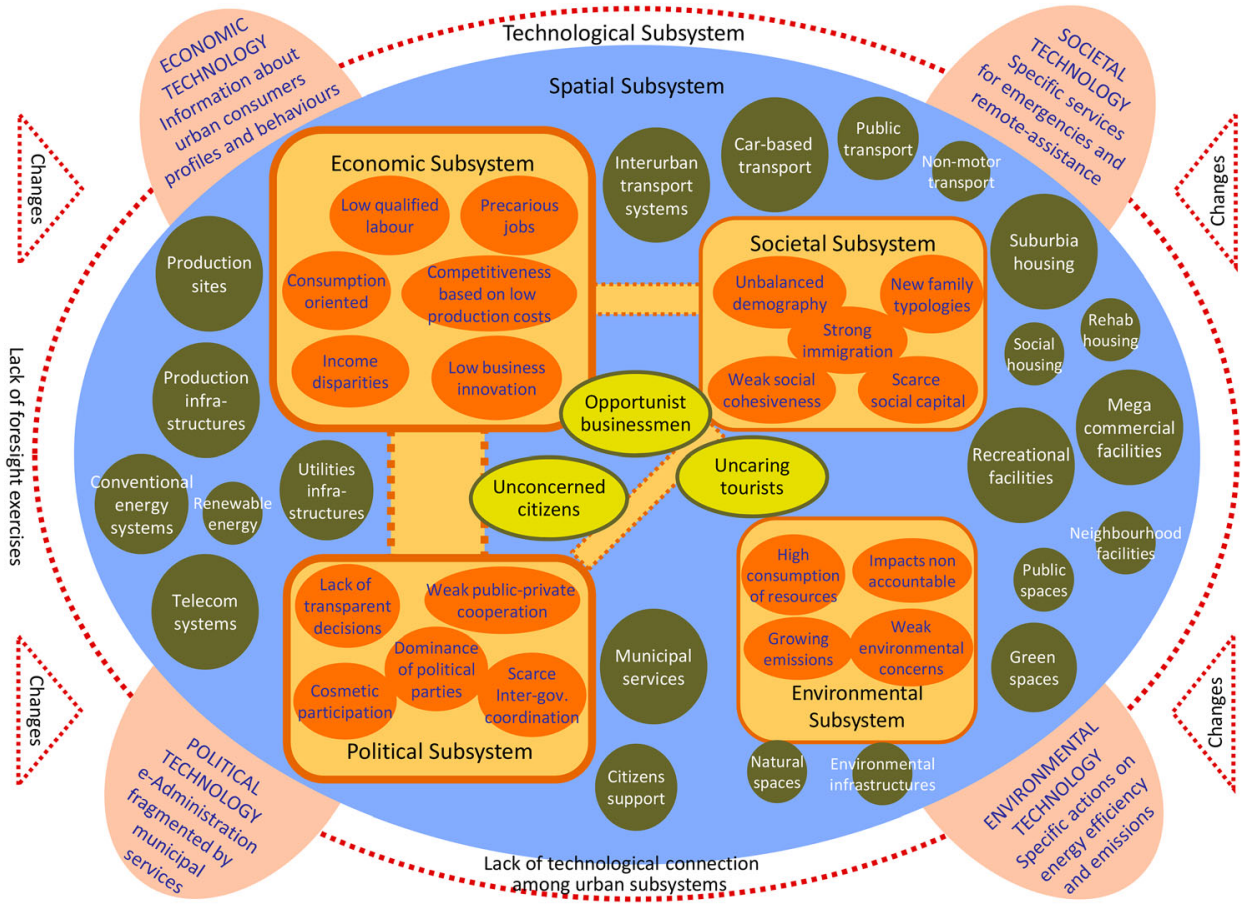

Figure 4: The functional system of Spanish cities in the pre-crisis period (2000-2008). Source: Authors' elaboration

scarcely qualified immigrants from developing countries, and the emergence of new family structures. As a result of the previous tensions, social capital was not significantly strengthened in the cities.

Environmental Subsystem. It was relegated to a secondary position within urban priorities during this period. The prevailing economic dynamism gave impulse to the aggressive urbanization of urban outskirts as well as to the construction of large transport infrastructures and commercial facilities. Due to rapid urban growth, numerous adverse environmental impacts occurred in the environs of cities.

Political Subsystem. At that time, local governments held positions very closed to the economic subsystem. There was an evident collusion of interests between economic stakeholders and local politicians in big real estate operations, which were favored by the lack of transparency in the municipal decision-making process. This state of things gave place to numerous episodes of corruption.

Spatial Subsystem. The behavior of the societal, economic, environmental, and political subsystems transformed the spatial subsystem of Spanish cities. Large areas were urbanized in the city fringes, big transport infrastructures were built for improving urban mobility and accessibility, costly commercial mega facilities were developed in the suburbs, and more houses were built than were needed. In other words, cities were overbuilt increasing their ecological footprint.

Technological Subsystem. During those years, Spanish municipalities made a significant effort to improve their management systems by incorporating new information and communication technologies (ICTs) to satisfy sectoral needs of specific municipal services. Smart initiatives began to appear in large and 
medium-size cities, mostly under the format of technological silos without much interaction among government departments and other city systems.

Futures Studies. Few and partial foresight exercises were undertaken during this period. Scattered initiatives, mostly sponsored by sectoral stakeholders, were undertaken to foresee the future evolution of the Spanish society, economy, or technology. At the city level, some municipalities carried out vision and scenarios exercises as part of their strategic plans.

Not all the city functional subsystems were effectively interconnected during this period. A strong relationship was developed between the economic and political subsystems due to their shared common interests. The societal subsystem had weaker connections with the economic and political realms; in fact, connections were activated on intermittent bases according to pressing needs such as political elections or labor unrest. Regarding the environmental subsystem, it operated in a rather isolated mode because other sectoral policies did not show much concern for environmental issues.

By 2008, the economic crisis was in full swing, producing a tough shock to most Spanish municipalities. At that point, it was clear that previous urban practices had aggravated the intensity and scope of the recession, generating a huge real estate bubble. If Spanish cities had to recover in a near future, despite amending past mistakes, they would have to assess the foreseeable impact of change factors in coming years. Thus, a foresight exercise was needed to envision the model of the future city.

\section{Step 3: Incorporate Foresight Tools to Envision the Future of Cities}

The foresight process was initiated by a scenario design exercise to expose all alternative paths that Spanish cities could follow towards the 2030 horizon. Scenario design was chosen because it provided an adequate management of the topic's complexity and uncertainty while at the same time unfolding alternative futures. Scenario design is a foresight technique that has been widely used and documented (Schwartz, 1991; van der Heijden, 1996). It is eminently qualitative, combining intuition and rational analysis, and requiring the collaboration of a group of experts.

The foresight exercise followed the conventional scenario design methodology made up of four sequential stages: (1) identify change factors that may affect cities and assess them for impact and uncertainty; (2) cluster critical uncertainties or key drivers into two scenario axes; (3) construct scenarios and develop narratives; (4) determine scenarios implications. This exercise relied all the way on a systematic, ongoing participation process with urban experts.

According to this method, key drivers affecting Spanish cities in the 2030 horizon were grouped into two axes, also called scenarios axes:

- Vertical axis: Represented the potential evolution of local stakeholders and urban policies in the next 15 years. This axis encompassed all future uncertainties related to social behavior, economic models, and public policies.

- Horizontal axis: Showed the potential evolution of the context in which Spanish cities may operate. This axis included all critical uncertainties regarding the societal, technological, economic, institutional, and environmental context. 
These axes gave rise to four distinct scenarios (See Figure 5) into which Spanish cities may evolve by the year 2030. A brief explanation of the four scenarios is provided below.

Scenario A: Innovative Cities. It represents cities that will quickly anticipate and adapt to the conditions of a very dynamic context thanks to the progressive attitude of local stakeholders who will promote innovative urban policies. To prosper in this scenario, Spanish cities will need ample capabilities and abundant resources to transform their societal, economic, environmental, and governance models.

Scenario B: Opportunistic Cities. It shows a type of city that will evolve in a dynamic and prosperous context, but their stakeholders will act in a very conservative and opportunistic way. In other words, local stakeholders will simply take advantage of favorable contextual conditions without undertaking profound transformations in their cities. In this scenario, cities will risk sliding into a structural crisis, which may eventually lead to urban decline.

Scenario C: Reinventing Cities. It describes cities that will experience a long deteriorating process caused by adverse contextual conditions. Faced with these conditions, local stakeholders will react decidedly to reinvent the urban development model. This scenario will require shock actions to revive the social and economic fabric of the city and to transform the governance model. Innovation and creativity will be the key factors to take advantage of the scarce development opportunities.

Scenario D: Declining Cities. It displays cities that will go through deep social, economic, and environmental problems, while their stakeholders will not be capable of reacting to a very adverse context. The lack of alternative options will inevitably lead these cities into decline. The only way out is to renew local leadership and pass along to Scenario $C$ for transforming the socioeconomic model.

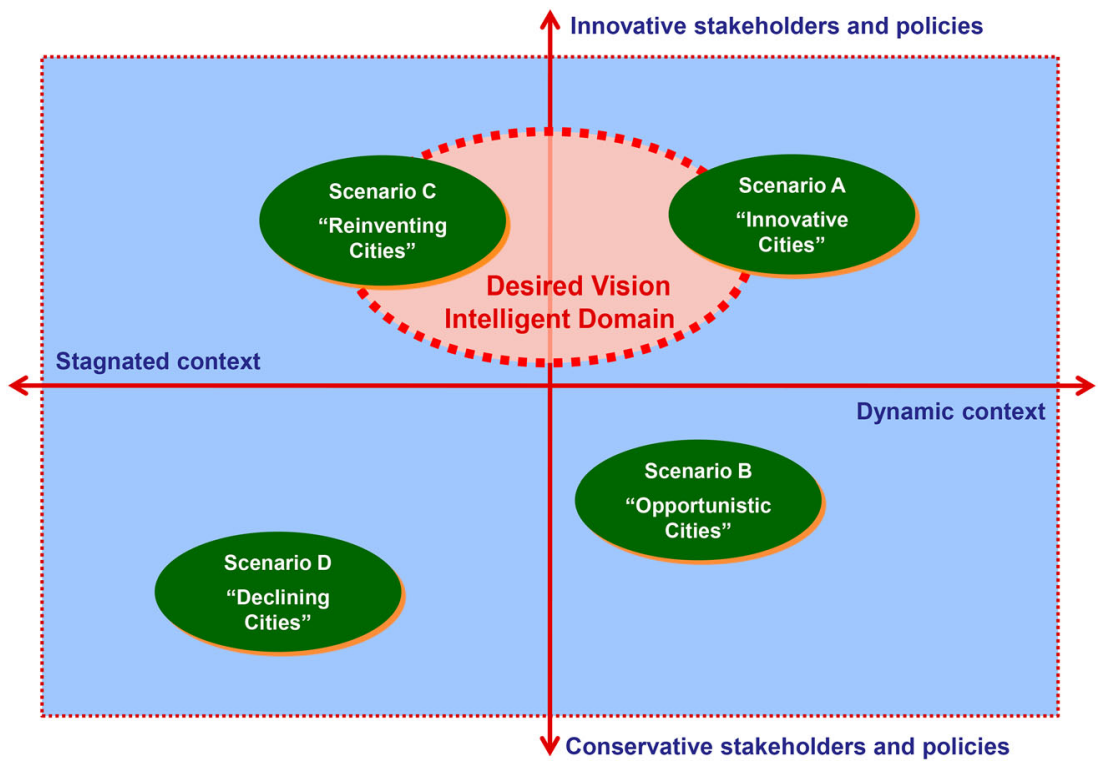

Figure 5: Alternative scenarios for Spanish cities in 2030. Source: Authors' elaboration 
None of these scenarios represents an exact prediction of future events; they simple constitute exploratory hypotheses of what may happen under certain conditions in the 2030 horizon. To solve the inevitable uncertainties that generate alternative scenarios, our study went one step further and incorporated a "desired vision" (Shipley and Newkirk, 1999; Shipley 2002) in between Scenario $A$ and C (See Figure 5). This vision would correspond to an "intelligent domain" for Spanish cities, which would act as a robust alternative to both favorable and unfavorable contexts. The difference between "vision" and "scenarios" is that a vision is normative because it formulates a preferred future, while scenarios are explorative because they display different futures (Fernández Güell, 2011).

After successive discussions with stakeholders and experts, it was agreed that the future desired vision was to be guided by five driving principles: (1) create an equitable and cohesive social fabric; (2) develop an innovative, competitive, and resilient economic base; (3) preserve a healthy and sustainable environment; (4) establish a collaborative and transparent governance system; (5) build a compact and sustainable urban structure. In other words, the "desired vision" was clearly for innovative urban policies supported by strongly committed stakeholders.

\section{Step 4: Flesh out the Vision's Implications on the Functional System}

Those five principles support the urban functional system which displays the desired future vision for Spanish cities (See Figure 6). Once more, the forthcoming future visions are synthesized from the contributions made by the experts during the foresight exercise.

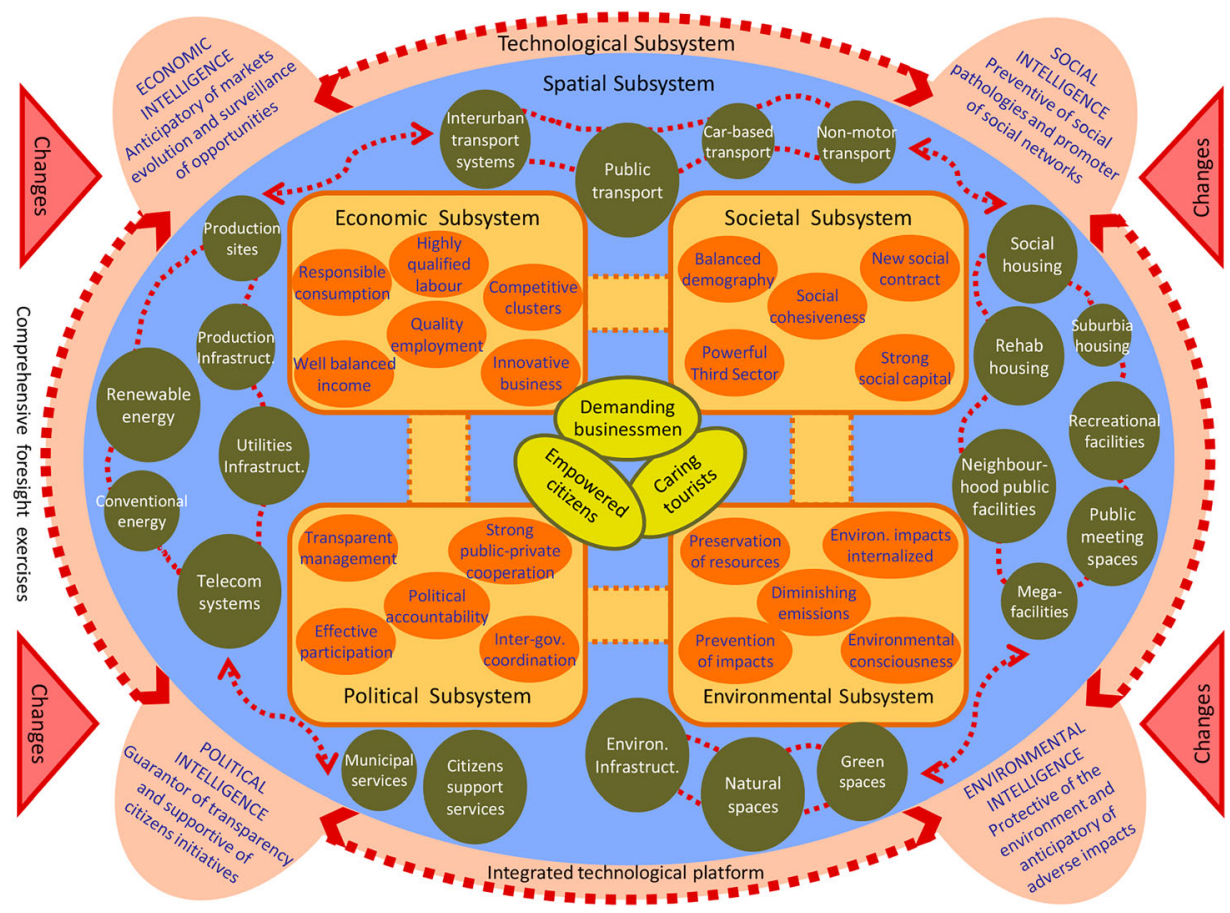

Figure 6: Future vision of the functional system of Spanish cities (2030) Source: Authors' elaboration 
All the functional subsystems will be tightly interconnected among themselves and they will take into account the needs, demands, and aspirations of the diverse urban demand segments in pursuit of a more integrated model. City managers will avoid dominant positions among the subsystems by establishing relatively well-balanced positions among demands and urban functions. This will compel urban planners to maintain fluid communications and negotiations with different stakeholders.

Vision of Urban Demand. In 2030, Spanish cities will be inhabited by citizens, businesses, and public organizations capable of facing problems and challenges in a creative and innovative way. Business will be very demanding on location requirements, but at the same time they will show a collaborative attitude with public officials for improving the city. Citizens will be empowered to exercise their rights, and they will be very much involved in public debates. Tourists will show high expectations regarding the environmental quality and social cohesiveness of city destinations.

Vision of the Economic Subsystem. Development in 2030 will be more balanced than in prior times. Economic development will be intelligent (based on knowledge, innovation, and creativity), sustainable (efficient use of resources and concern for the environment), and cohesive (high level of employment and social responsibility). Sectors with well-articulated clusters of business, technology centers, advanced services, and entrepreneurs will flourish and will be more resilient during economic downturns.

Vision of the Societal Subsystem. In the future, cities will be faced with significant challenges such as an aging population, the emergence of new exclusionary pathologies, and a growing multicultural society. Cities will establish a new social pact among generations and genders so as to provide adequate assistance to the most needed and handicapped. Resources will be redistributed in an equitable and efficient way to attend social needs and minimize social gaps.

Vision of the Environmental Subsystem. In 2030, Spanish cities will prosper in economic and social terms, but at the same time they will reduce their ecological footprint by diminishing the consumption of energy, water, soil, and other natural resources. Success will be due to technological innovations that will minimize environmental impacts, but also to the growing environmental consciousness of citizens who will have significantly reduced their consumption levels.

Vision of the Political Subsystem. Advanced governance will be a must in the cities of the future. Local administrations will be more intelligent, innovative, transparent, accountable, participative, and inclusive because citizens will be more empowered and socially active than ever before. The increasing involvement of citizens in city matters will give rise to an improved and responsible political class, capable of responding to social demands with adequate policies.

Vision of the Spatial Subsystem. In 2030, cities will shape their physical elements according to strict sustainability criteria. Spanish cities will opt for compact, complex, and efficient urban models over sprawl and low-density models. Among other features, urban mobility will be dominated by public transport and non-motorized modes, while carefully designed public spaces and community facilities will foster the social encounter of citizens.

Vision of the Technological Subsystem. The effective development of truly Smart Cities will require the coordination of numerous agents and technologies as well as the long-term involvement of local stakeholders. In this visionary model, the relations among demand segments and functional subsystems will be supported 
by complex technology platforms that will supply fluid communications in real time among the diverse parts of the urban system. In simpler terms, these platforms and their embedded technologies will provide effective intelligence to cities.

Futures Studies. Cities which pretend to be smart will have to scan constantly the context in which they are operating. Scanning the context will mean monitoring and anticipating all the geopolitical, societal, economic, technological, and environmental change factors that may affect the city's development. Those foreseeable changes will be analyzed not only by advanced quantitative models but will be contrasted by experts who will give qualitative opinions.

In brief, the complexity and dimension of forthcoming challenges will impel cities to interconnect and coordinate their functional subsystems. Consequently, the Smart City of the future will have to be planned and managed under a holistic approach, making sure that all urban functions and city agents operate in an integrated and related way.

\section{Step 5: Involve Experts and Stakeholders}

As stated before, stakeholders' involvement during the entire process is a critical element of the proposed approach. To properly fulfill this requirement, in-depth interviews were conducted to SC stakeholders to validate the urban functional system and the future vision for Spanish cities. Among others, five major issues were covered during the interviews:

- What is the stakeholder's present approach to SC initiatives?

- What is the stakeholder's attitude toward a systemic approach in SCs?

-What is the stakeholder's present use of foresight tools in SC initiatives?

- What is the stakeholder's attitude toward incorporating foresight tools in SCs?

- What is the stakeholder's attitude toward a joint systemic and foresight approach?

Evidence and perceptions gathered by the authors are synthesized in Table 1 . In the first column, stakeholders are identified by the role they played in SC initiatives. The following columns present a brief statement on stakeholders' positions on the five issues.

Though the table is quite self-explanatory, here are some hints about the reaction of the stakeholders who were interviewed about the proposed approach.

(1) At the time they were consulted, stakeholders were mainly developing sectoral SC initiatives related to their field of knowledge and professional practice, though they were fully aware of the need for progressing toward more integrated and holistic applications.

(2) Their attitude toward systemic approaches varied from simple ignorance to affirmative interest. Those most interested admitted present technical limitations to reach a workable holistic vision of contemporary cities.

(3) Their present use of foresight tools to explore future developments in SC initiatives was rather limited. Despite the use of conventional forecasting methods to anticipate demand, they hardly employed qualitative methods such as scenarios or visions.

(4) Their attitude toward incorporating foresight tools in SC initiatives was mildly receptive, though dubious of the reliability and real effectiveness of those methods. 
Table 1: Stakeholders' attitudes toward the proposed approach

\begin{tabular}{|c|c|c|c|c|c|}
\hline $\begin{array}{l}\text { Participant stakeholders } \\
\text { directly involved in } \\
\text { promoting SC initiatives }\end{array}$ & $\begin{array}{c}\text { Present approach to SC } \\
\text { initiatives }\end{array}$ & $\begin{array}{c}\text { Attitude toward a systemic } \\
\text { approach to SCs }\end{array}$ & $\begin{array}{l}\text { Present use of foresight } \\
\text { tools in SC initiatives }\end{array}$ & $\begin{array}{c}\text { Attitude toward } \\
\text { incorporating foresight } \\
\text { tools in SCs }\end{array}$ & $\begin{array}{l}\text { Attitude toward a joint } \\
\text { systemic \& foresight } \\
\text { approach }\end{array}$ \\
\hline $\begin{array}{l}\text { Association of Spanish } \\
\text { municipalities } \\
\text { developing SC } \\
\text { initiatives }\end{array}$ & $\begin{array}{l}\text { Promoters of sectoral } \\
\text { initiatives and best } \\
\text { practices among cities }\end{array}$ & $\begin{array}{l}\text { Aware of the need of more } \\
\text { integrated approaches, } \\
\text { but not ready for } \\
\text { pushing them }\end{array}$ & $\begin{array}{l}\text { Limited to trend analysis } \\
\text { related to technological } \\
\text { innovations }\end{array}$ & $\begin{array}{l}\text { Little awareness of most } \\
\text { municipalities } \\
\text { toward foresight tools }\end{array}$ & $\begin{array}{l}\text { Interested in the long-term, } \\
\text { but now distracted with } \\
\text { short-term challenges }\end{array}$ \\
\hline $\begin{array}{l}\text { City department in } \\
\text { charge of SC } \\
\text { initiatives in a large } \\
\text { metropolis }\end{array}$ & $\begin{array}{l}\text { Developing a } \\
\text { technological platform } \\
\text { for integrating SCs } \\
\text { public initiatives }\end{array}$ & $\begin{array}{l}\text { Receptive to integrating } \\
\text { public and private SC } \\
\text { initiatives in platforms }\end{array}$ & $\begin{array}{l}\text { Limited experience with } \\
\text { future visions as part of } \\
\text { their city's strategic } \\
\text { plan }\end{array}$ & $\begin{array}{l}\text { Potential applicants of } \\
\text { foresight tools to } \\
\text { guide future SC } \\
\text { initiatives }\end{array}$ & $\begin{array}{l}\text { Most likely interested in } \\
\text { testing demos of a joint } \\
\text { approach }\end{array}$ \\
\hline $\begin{array}{l}\text { City department in } \\
\text { charge of managing } \\
\text { service providers in } \\
\text { the capital city }\end{array}$ & $\begin{array}{l}\text { Developing a } \\
\text { technological platform } \\
\text { for integrating service } \\
\text { providers }\end{array}$ & $\begin{array}{l}\text { Interested in developing } \\
\text { "Intelligent Contracts" } \\
\text { with business providers }\end{array}$ & $\begin{array}{l}\text { Limited to trend analysis } \\
\text { related to technological } \\
\text { innovations }\end{array}$ & $\begin{array}{l}\text { Little awareness of } \\
\text { foresight tools } \\
\text { capabilities }\end{array}$ & $\begin{array}{l}\text { Potentially interested if it } \\
\text { provides technical and } \\
\text { economic benefits }\end{array}$ \\
\hline $\begin{array}{l}\text { Technology department } \\
\text { of a regional public } \\
\text { transport authority }\end{array}$ & $\begin{array}{l}\text { Integrated approach to all } \\
\text { issues related to } \\
\text { transport planning \& } \\
\text { management }\end{array}$ & $\begin{array}{l}\text { Interested in linking } \\
\text { transport, land use, } \\
\text { business location, and } \\
\text { customer behavior }\end{array}$ & $\begin{array}{l}\text { Limited to sophisticated } \\
\text { models for forecasting } \\
\text { traffic demand and } \\
\text { flows }\end{array}$ & $\begin{array}{l}\text { Doubts about } \\
\text { incorporating } \\
\text { foresight tools with } \\
\text { traffic forecasting } \\
\text { models }\end{array}$ & $\begin{array}{l}\text { Potentially interested if it } \\
\text { can improve transport } \\
\text { models and customer- } \\
\text { oriented applications }\end{array}$ \\
\hline $\begin{array}{l}\text { Ministry in charge of } \\
\text { urban policy making } \\
\text { at the national level }\end{array}$ & $\begin{array}{l}\text { Interested in SC } \\
\text { initiatives that develop } \\
\text { integrated urban } \\
\text { information systems }\end{array}$ & $\begin{array}{l}\text { Mostly interested in } \\
\text { integrating spatial } \\
\text { planning \& } \\
\text { environmental issues }\end{array}$ & $\begin{array}{l}\text { Monitoring } \\
\text { environmental and } \\
\text { technology trends } \\
\text { related to spatial } \\
\text { planning }\end{array}$ & $\begin{array}{l}\text { Little awareness of } \\
\text { foresight tools } \\
\text { capabilities }\end{array}$ & $\begin{array}{l}\text { Potentially interested if it } \\
\text { provides environmental } \\
\text { and planning benefits }\end{array}$ \\
\hline $\begin{array}{l}\text { University transport } \\
\text { research center } \\
\text { focused on SC } \\
\text { initiatives }\end{array}$ & $\begin{array}{l}\text { Developers of sectoral SC } \\
\text { initiatives and studies } \\
\text { related to transport } \\
\text { issues }\end{array}$ & $\begin{array}{l}\text { Interested in linking } \\
\text { transport issues with } \\
\text { other urban activities }\end{array}$ & $\begin{array}{l}\text { Focused in transport } \\
\text { models and cross } \\
\text { impact analysis }\end{array}$ & $\begin{array}{l}\text { Little experience in } \\
\text { incorporating } \\
\text { foresight into } \\
\text { transport studies }\end{array}$ & $\begin{array}{l}\text { Potentially interested if it } \\
\text { helps to comprehend } \\
\text { urban complexity }\end{array}$ \\
\hline
\end{tabular}


University industrial research center focused on SC applications

Municipal garbage
service provider
interested in SC
applications

Telecom operator fully involved in developing the SC business

\begin{tabular}{l} 
IT consultant \\
specialized in \\
commercial \\
development of SC \\
initiatives \\
\hline Internet corporation \\
$\quad$ with growing interest \\
in SC applications
\end{tabular}

Developers of sectoral SC Interested in extending initiatives related to energy-efficiency issues

Developers of specific SC initiatives for the provision of multiple urban services

Developers of a transversal and open tech platform for integrating various application energy-efficiency applications to city scale service providers \& for SC initiatives
Limited to trend analysis and monitoring technological innovations
Little awareness of foresight tools capabilities
Potentially interested if it improves efficiency of urban energy grids
Developers of advanced software and tech platforms to run SC initiatives
Interested in linking their sectoral activities with other business opportunities

\section{Limited to the use of} demand forecasting models

Interested in incorporating Focused on forecasting application developers

Interested in developing fully integrated approaches to manage $\mathrm{SC}$ initiatives models to foresee demand and technology evolution
Limited to trend analysis and monitoring technological innovations

\section{Little awareness of foresight tools capabilities}

Potential applicants of foresight tools to promote future SC initiatives
Potentially interested if it provides technical and economic benefits
Potentially interested for scanning new business opportunities
Potential applicants of foresight tools to develop future SCs initiatives
Potentially interested if it provides technical and economic benefits
Developers of a wide range of Internet applications focused on the needs of urban users

\author{
Interested in developing \\ all kind of bottom-up SC \\ initiatives
}
Potential intensive users Potentially interested to of foresight tools explore and develop new business opportunities


(5) Their attitude toward using a joint systemic and foresight approach in the future was positive, provided that the tools were sufficiently refined to offer tangible benefits.

Those results suggest the necessity of developing an integrated management scheme for Smart Cities under a systemic approach, reinforced by foresight tools.

\section{Discussion of Results}

From the findings gathered during our research, a number of positive contributions can be drawn from the proposed joint systemic and foresight approach to Smart Cities.

First of all, based upon process experiences and feedback given at the end of the foresight exercise, participant stakeholders welcomed the greater clarity about the functionality of a contemporary city and the future vision of complex urban systems. By providing systematic guidance on the foreseeable evolution of the urban functional system, participants profited from the exercise by gaining an improved insight into the relational complexities of cities.

Second, the proposed approach appeared to be user-friendly for decisionmakers and stakeholders, and quite manageable for technicians. Although the approach just provided a functional schematic vision of a city, it generated a graphical display of a very complex system, which people could easily refer to and understand. Thus, the present approach eased the collaboration among diverse stakeholders and advanced meaningful representations of complex realities.

Third, both the systemic and foresight approaches worked well together to envision SC initiatives as part of a holistic approach to cities. Confronted with the display of the city's functional subsystems and their evolution over time, participants were capable of establishing how much integrated were present SC initiatives and how they should evolve in the coming years. Discussions revealed the different meaning of the term "holistic" between urban planners and technologists: the former perceive it as the integration of sectoral issues into a common planning process and the latter as the integration of software applications into a common technological platform.

Fourth, the method provides an opportunity to breach the gap between SC stakeholders and spatial planners. The broad understanding of the city as a composite of different subsystems, which are tightly interrelated among themselves and with their operating context, counterbalances the banality of many contemporary versions of SCs. Moreover, this approach may help to determine the implications of massive introduction of ICTs to cities, forcing the reinterpretation of the SC concept.

However, in its present state of development, the proposed model has several limitations. First and most importantly, it is just a generic and conceptual framework that needs to be applied to real cities in order to test rigorously its feasibility. This test will enable researchers to check the plausibility of the approach and will provide planners with a road map for improving SC initiatives.

Second, more exploratory work should be done with stakeholders' involvement in interpreting the functional system to guarantee that they can add value when discussing SC initiatives. Further work needs to be done in identifying appropriate methods of enquiry to better understand network interrelations 
among stakeholders. Likewise, the degree to which this kind of foresight exercise facilitates capacity building among key urban stakeholders remains to be checked.

Third, the method, as it is right now, does not contemplate the possibility of plugging in quantitative models that would certainly enrich the whole approach. A concurrent use of quantitative and qualitative tools would improve the accuracy of foresight exercises. Thus, quantitative tools could be employed to support and lend coherence to the process, but they should never drive it because the method would lose its eminently qualitative nature and would discourage stakeholders' involvement.

The above-mentioned limitations expose clear opportunities for further lines of enquiry that bring together academicians and professionals working in the practice of Smart Cities. Execution of further research will enhance the potential of this approach for incorporating foresight as an undisputed work package in the planning of SC initiatives.

\section{Conclusions}

This paper has raised two major issues regarding the development of Smart City initiatives. First, there is a need for employing systemic approaches to deal with the attributes of complexity and diversity, inherent to most contemporary cities. Second, incorporating foresight tools in the process of designing and implementing SC initiatives may help to manage the inevitable urban uncertainty.

A first set of conclusions related to the systemic approach can be drawn from our paper. Understanding the city as a functional system will allow for an integrated and iconic representation of urban complexity which will be intelligible to most stakeholders. This approach will provide information about how particular subsystems deal with contextual issues and how they interact among themselves and develop over time. Increased knowledge about subsystems working will improve their operational effectiveness by incorporating technology or other technical resources. So too, a systemic approach will facilitate the identification of urban stakeholders, their roles, and power relations within the community. Finally, under this approach, technology will appear in the city not like the dominant player, but as a set of tools that will improve functions and will support, in an integrated fashion, the operations of the whole functional system.

A second group of conclusions refer to the application of foresight tools. Futures studies are well equipped for providing holistic visions of how cities will evolve in the long term, thus helping to assess alternative development policies. In fact, foresight tools are particularly useful for exploring the foreseeable impacts of technology on cities. So too, storytelling, a common technique in scenario design, will surely facilitate stakeholders' involvement in decision making. As a matter of fact, urban planners and stakeholders will increasingly appreciate the role of foresight to manage uncertainty by anticipating unforeseen circumstances. Finally, foresight is a valuable input to the strategic planning of cities because it defies conventional wisdom about how change drivers, such as technology, will affect the evolution of cities.

The conjunction of a systemic approach with foresight tools will certainly reinforce urban analyses and provide solid grounds for development strategies, 
especially when dealing with Smart City initiatives. Both approaches will take into consideration the three key features of contemporary cities-complexity, diversity, and uncertainty-and will allow for the integration of the elements of the SC. Indeed, the systemic approach will provide foresight exercises, a manageable support to envision a long-term horizon without losing the complexity and diversity of the analyzed object: the city.

Finally, some conclusions can also be extracted about Smart Cities themselves. As some authors have expressed in the last few years (Papa et al., 2013; Angelidou, 2014; Hollands, 2015), SC initiatives should not solely rely on technological solutions to face the challenges of contemporary cities but they should deploy a wider array of resources. In fact, technological smartness is just one among other intelligences that a city has; to be really smart, cities will have to incorporate other values-social and cultural-in order to reach a more equitable and sustainable society. In other words, human-centered approaches to urban challenges will be an indispensable characteristic of the Smart City, putting technology truly at the service of urban inhabitants and not vice versa.

As stated before, SC initiatives run the risk of simplifying urban concepts and models, so we should turn around the tech discourse and relocate technology as a transversal supportive element of the whole urban functional system. In that respect, well-proofed urban design solutions along time, such as plazas and public markets, should not be disregarded but on the contrary reinforced by technology. Likewise, urban planning grounded in a holistic approach might play a key role in incorporating SC initiatives in synchrony with urban development goals and citizens' needs.

In summary, this paper shows the potential of systemic approaches and foresight tools for adding value and making sense of present Smart City initiatives, which do not seem fully capable of confronting the complexity, diversity, and uncertainty of contemporary cities.

\section{Disclosure Statement}

No potential conflict of interest was reported by the authors.

\section{Notes on Contributors}

José-Miguel Fernández-Güell is deputy director of research at the School of Architecture, Universidad Politécnica de Madrid (UPM), Spain. He is a professor in the Urban and Regional Planning Department at UPM.

Marta Collado-Lara is a doctoral student in the Urban and Regional Planning Department at UPM.

Silvia Guzmán-Araña is a doctoral student in the Urban and Regional Planning Department at UPM.

Victoria Fernández-Añez is a doctoral student in the Urban and Regional Planning Department at UPM. 


\section{Bibliography}

J. Abott, “Understanding and Managing the Unknown: the Nature of Uncertainty in Planning," Journal of Planning Education and Research 24 (2005) 237-251.

C. Alexander, "A City is not Tree," Architectural Forum 122: 1 (1965) 58-61.

P.M. Allen, "Cities and Regions as Evolutionary Complex Systems," Geographical Systems 4 (1997) 103-130.

M. Angelidou, "Smart City Policies: A Spatial Approach," Cities 41 (2014) S3-S11.

M. Batty, Cities and Complexity: Understanding Cities with Cellular Automata, Agent-Based Models, and Fractals (Cambridge, MA: The MIT Press, 2005).

M. Batty, K.W. Axhausen, F. Giannotti et al., "Smart Cities of the Future," The European Physical Journal Special Topics 214 (2012) 481-518.

L. Bertalanffy, General Systems Theory: Foundations, Development and Applications (New York: Braziller, 1968).

B.J. Berry, “Cities as Systems Within Systems of Cities," Papers in Regional Science 13: 1 (1964) 147-163.

M. Boden, C. Cagnin, V. Carabias, K. Haegeman and T. Könnölä, Facing the Future: Time for the EU to Meet Global Challenges (Sevilla: Institute for Prospective Technological Studies, 2010).

R. Camagni, "Incertidumbre, Capital Social Y Desarrollo Local: Enseñanzas Para una Gobernabilidad Sostenible del Territorio," Investigaciones Regionales 2 (2003) 31-57.

T. Campbell, Beyond Smart Cities: How Cities Network, Learn and Innovate (New York: Routledge, 2012).

A. Caragliu, C. Del Bo and P. Nijkamp, "Smart Cities in Europe," Journal of Urban Technology 18: 2 (2011) 65-82.

H. Chourabi, T. Nam, S. Walker, J. Gil-García, S. Mellouli, K. Nahon, T.A. Pardo and H. Scholl, “Understanding Smart Cities: An Integrative Framework," Proceedings of 45th Hawaii International Conference on Systems Science, HICSS-45 2012, 4-7 (Maui, 2012).

W. Churchman, The Systems Approach (New York: Delacorte Press, 1968).

Cisco, Smart + Connected Communities Platform Offers Solutions in Fields Such as Transportation, Learning, Safety and Security, Sports and Entertainment, Utilities, Real Estate, Health and Government (San José, CA: CISCO, 2013).

European Commission (EC), Cities of Tomorrow: Challenges, Visions, Ways Forward (Brussels: European Commission, Directorate General for Regional Policy, 2011).

European Commission (EC), Communication from the Commission on Smart Cities and Communities European Innovation Partnership, Brussels, C (2012) 4701 Final (10-07-2012).

European Commission (EC), European Innovation Partnership on Smart Cities and Communities: Strategic Implementation Plan (Brussels: European Commission, 2013).

J. Fariña, "Smart Cities, los inventos del TBO," El Blog de Fariña (2012) < http://elblogdefarina. blogspot.com.es> Accessed June 11th, 2015.

J.M. Fernández Güell, Planificación estratégica de ciudades: nuevos instrumentos y procesos (Barcelona: Editorial Reverté, 2006).

J.M. Fernández Güell, “Recuperación de los Estudios del Futuro A Través de la Prospectiva Territorial," Ciudad Y Territorio - Estudios Territoriales 167 (2011) 11-32.

J.M. Fernández Güell, “Ciudades Inteligentes: La mitificación de las nuevas tecnologías como respuesta a los retos de las ciudades contemporáneas," Economía Industrial 395 (2015) 17-28.

J.M. Fernández Güell and M. Collado, Ciudades y ciudadanos en 2033: La transformación urbana de España (Madrid: PricewaterhouseCoopers y Fundación EOI, 2014).

Foresight for Regional Development Network (FOREN), Practical Guide to Regional Foresight (Sevilla: Institute for Prospective Technological Studies, 2001).

J.W. Forrester, Urban Dynamics (Cambridge, MA: MIT Press, 1969).

F. Gaja i Díaz, "Reparar los impactos de la burbuja constructora," Scripta Nova 517 (2015) 1-37.

R. Giffinger, C. Fertner, H. Kramar, R. Kalasek, N. Pichler-Milanovic and E. Meijers, Smart Cities: Ranking of European Medium-Size Cities (Vienna: Centre of Regional Science, Vienna University of Technology, 2007).

J.R. Gil-García, T.A. Pardo and T. Nam, "A Comprehensive View of the 21st Century City: Smartness as Technologies and Innovation in Urban Contexts," in J.R. Gil-García et al., eds., Smarter as the new Urban Agenda: A Comprehensive View of the 21st Century City (Switzerland: Springer International Publishing, 2015) 1-19.

A. Glasmeier and S. Christopherson, "Thinking About Smart Cities," Cambridge Journal of Regions, Economy and Society 8 (2015) 3-12.

A. Greenfield, Against the Smart City (New York: Do projects, 2013).

K. van der Heijden, Scenarios: The Art of Strategic Conversation (London: Wiley, 1996). 
R. Hollands, "Will the Real Smart City Stand up? Intelligent, Progressive, or Entrepreneurial?" City 12: 3 (2008) 303-320.

R. Hollands, "Critical Interventions Into the Corporate Smart City," Cambridge Journal of Regions, Economy and Society 8 (2015) 61-77.

IBM, A Vision of Smarter Cities: How Cities can Lead the Way Into A Prosperous and Sustainable Future (New York: IBM Institute for Business Value, 2009).

J. Innes and D. Booher, "Consensus Building and Complex Adaptive Systems: A Framework for Evaluating Collaborative Planning," Journal of the American Planning Association 65: 4 (1999) 412-423.

J. Jacobs, The Death and Life of Great American Cities (New York: Random House, 1961).

F. Jiménez, "Building Boom and Political Corruption in Spain," South European Society and Politics 14: 3 (2009) 255-272.

S. Kauffman, At Home in the Universe: the Search for the Laws of Self-Organization and Complexity (New York: Oxford University Press, 1995).

R. Kitchin, "Making Sense of Smart Cities: Addressing Present Shortcomings," Cambridge Journal of Regions, Economy and Society 8 (2015) 131-136.

R. Klosterman, "Lessons Learned About Planning: Forecasting, Participation, and Technology," Journal of the American Planning Association 79 (2013) 161-169.

P. Lombardi, S. Giordano, H. Farouh and W. Yousef, "Modelling the Smart City Performance," Innovation: The European Journal of Social Science Research 25: 2 (2012) 137-149.

H. March and R. Ribera-Fumaz, "Smart Contradictions: The Politics of Making Barcelona A Self-Sufficient City," European Urban and Regional Studies (2014). doi:10.1177/0969776414554488 (2014).

B. Mattoni, F. Gugliermetti, and F. Bisegna, "A Multilevel Method to Assess and Design the Renovation and Integration of Smart Cities," Sustainable Cities and Society 15 (2015) 105-119.

J.B. McLoughlin, Urban and Regional Planning: A Systems Approach (New York: Praeger, 1969).

R. Meyers (editor), Encyclopaedia of Complexity and Systems Science (New York: Springer, 2009).

Ministerio de Industria, Energía y Turismo (MINETUR), Ciudades Inteligentes: agenda digital para España (Madrid: MINETUR, 2015).

G. Misuraca and W. Lusoli (editors), Envisioning Digital Europe 2030: Scenarios for ICT in Future Governance and Policy Modeling (Sevilla: Institute for Prospective Technological Studies, 2010).

J.M. Naredo and A. Montiel, El modelo inmobiliario español y su culminación en el caso valenciano (Madrid: Icaria, 2011).

Organization for Economic Co-operation and Development (OECD), Environmental Outlook to 2050: The Consequences of Inaction (Paris: OECD Publishing, 2012).

Organization for Economic Co-operation and Development (OECD), The Metropolitan Century: Understanding Urbanization and its Consequences (Paris: OECD Publishing, 2015).

S. Paroutis, M. Bennet and L. Heracleous, "A Strategic View on Smart City Technology: The Case of IBM Smarter Cities During A Recession," Technological Forecasting and Social Change 89 (2014) 262-272.

R. Papa, C. Gargiulo and A. Galderisi, “Towards an Urban Planners' Perspective on Smart City,” TeMA Journal of Land Use, Mobility and Environment 1 (2013) 5-17.

G. Perboli, A. De Marco, F. Perfetti and M. Marone, "A new Taxonomy of Smart City Projects," Transportation Research Procedia 3 (2014) 470-478.

J. Portugali, H. Meyer, E. Stolk and E. Tan, Complexity Theories of Cities Have Come of age: an Overview with Implications to Urban Planning and Design (New York: Springer, 2012).

PricewaterhouseCoopers (PwC), The World in 2050. The Accelerating Shift of Global Economic Power: Challenges and Opportunities (London: PwC, 2011).

P. Schwartz, The Art of the Long View (New York: Doubleday Currency, 1991).

R. Shipley, "Visioning in Planning: is the Practice Based on Sound Theory?" Environment and Planning A 34 (2002) 7-22.

R. Shipley and R. Newkirk, "Vision and Visioning in Planning: What do These Terms Really Mean?" Environment and Planning B: Planning and Design 26 (1999) 573-591.

Siemens, How Cities become Smart (2015) < https://www.siemens.com/innovation/en/home/picturesof-the-future/infrastructure-and-finance/smart-cities-dossier.html $>$ Accessed July 07, 2015.

O. Söderström, T. Paasche and F. Klauser, "Smart Cities as Corporate Storytelling," City 18: 3 (2014) 307-320.

A. Townsend, Smart Cities: Big Data, Civic Hackers and the Quest for new Utopia (New York: W. W. Norton \& Co, 2013).

UN-Habitat, Cities and Climate Change: Global Report on Human Settlements 2011 (London: Earthscan, 2011). 
United Nations Industrial Development Organization (UNIDO), UNIDO Technology Foresight Manual (Vienna: UNIDO, 2005).

United Nations, Department of Economic and Social Affairs (UN-DESA), World Urbanization Prospects: The 2014 Revision (2014) <http://esa.un.org/unpd/wup/Highlights/WUP2014-Highlights.pdf> Accessed June 30, 2015.

A. Vanolo, "Smartmentality: the Smart City as Disciplinary Strategy," Urban Studies 51: 5 (2014) 883-898.

M. Waldrop, Complexity: The Emerging Science at the Edge of Order and Chaos (New York: Simon \& Schuster, 1992). 